\title{
Identifying The Long-Run Relationship Of Real Money Demand, Real Income And Prime Interest Rates In South Africa
}

Ferdinand Niyimbanira, Vaal University of Technology, South Africa Job Dubihlela, Vaal University of Technology, South Africa

\begin{abstract}
This paper analyses the long-run demand for money in South Africa for the period 1971-2010. In particular, the paper estimates a co-integrated vector autoregression model of the long-run relationship between real money demand, real income and prime interest rate. A variety of theory consistent identification schemes, tests for co-integration, co-integration regression and errorcorrection-model (ECM) were applied in the order of the estimation approach developed by Johansen (1991). Preliminary data were also subjected to the autocorrelation function. Results show that the estimated elasticities indicate that a long-run equilibrium relationship exists between real money (M2), real income and the prime interest rate in South Africa. As expected, the coefficient of the equilibrium error term was found to be negative and significantly different from zero, implying that 0.227 of discrepancy between real money demand and its explanatory variables is eliminated in the following year. Evidence indicates that the retarded speed of adjustment for real money demand in South Africa needs about one year to re-adjust.
\end{abstract}

Keywords: Monetary Policy; Money Demand; Co-Integrated Vector Autoregression Model; Long-Run Relationship

\section{INTRODUCTION}

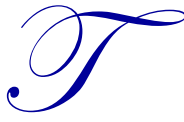

he importance of the behaviour of the money demand relationship to the formulation of successful monetary policy has long been acknowledged by economists. Demand for money refers to the amount of money that the people want to hold as assets (Henderson \& Poole, 1991), which is determined by a specified list of economic variables such as their income and cost of holding money. Real money balances represent the value in terms of its purchasing power of goods and services (Wesso, 2002). In other words, real money is the physical currency (i.e., number of notes and coins) and the deposits that the people are holding, deflated by a price level measure (deflation rate) to reflect its purchasing power (Whittaker, 1985). Generally, economists have avowed that the demand for money is the demand for real money balances (Todani, 2007).

The empirical properties of demand for money are vital considerations influencing the choices of monetary policy strategies in various economies (Bernanke, 2006; Ziramba, 2007). A steady stream of empirical research concedes that demand for money is fundamental in macroeconomic analysis, particularly in determining appropriate monetary policy decisions (Spencer, 1997). Research interest has heightened in recent years, triggered by the concerns among monetary authorities and researchers on the impact of various economic indicators (Kent \& Lowe, 1997). Research has also focused on the movement toward flexible exchange rate regime, the globalisation of capital markets, financial liberalisation and innovation, advancement in time series econometrics, and country-specific issues (Talvas, 1989). The implications and predictions that follow alternative demand for money hypotheses have been recognised to generate widely contrasting prescriptions of economic policy (Havrilesky, 1978). For a long time, demand for money has been topical in applied economics, particularly in developed economies. This is because an understanding of demand for money assists in understanding the reaction dynamics of macroeconomic aggregates to changes in money supply (Saunders \& Cornett, 2005). These macroeconomic dynamics have also 
increasingly become interesting research focus areas and subjects of discussion in most developing economies (Harb, 2003) in their quest to interpret and implement appropriate monetary policies.

The assumption of a stable long-run demand for money (i.e., of a long-run relationship between real money balances, real income and the prime interest rate) is one of the main building blocks of modern macroeconomic theory (Bernanke \& Gertler, 1999). Moreover, it is a basic requirement for any policy targeting a monetary aggregate as being practiced by the leading central banks for the past few decades (Falkena, Meijer \& Van der Merwe, 1991). The three key issues in an investigation of the demand for money are: (1) the choices of the appropriate measure of money, (2) the scale variable (i.e., income or wealth), and (3) the opportunity cost variable which is the short or the long-term interest rate (Haug \& Lucas, 1996).

Previous studies on demand for money in South Africa were done by Courakis (1984), Tavlas (1989), Hurn and Muscatelli (1992), Naude (1992), Moll (2000), Nell (2004), Wesso (2002), Tlelima and Turner (2004), Ziramba (2007), and Todani (2007). Building on this body of knowledge, the current study is motivated by the need for further empirical work in analysing the money demand behaviour in order to assess the impact of real income and the prime interest rate components. This particular study is different from the previous studies focusing on South Africa in that it employs a longer and more recent sample from 1970 to 2008. It also draws upon some latest advances in econometric time series modelling and uses these techniques as tools to re-assess real money demand. This methodology has only recently become widely available to applied economists, but because this model features extensively in the literature on co-integration, these methods can be used for analysis of the demand for money function.

This study begins with a literature section that provides relevant discussions regarding the fundamental theories of the demand for money. It goes on by briefly specifying the model that underlies the empirical formulation in estimating the demand for money, by providing an overview of the data, aggregation methods employed and examining the long-run time-series properties of the data in the context of multivariate co-integration analysis (Johansen, 1991) of systems comprising real money, real income and prime interest rate. Hereafter, the results are discussed and implications are provided in the concluding sections. The objective of this analysis is to assess whether a long-run relation between money demand and its explanatory variables exists within the South African economy.

The real issue is to know the difference between monetarist and Keynesian theorists. The answer is embedded in the three suggestions by Friedman (1988) that: (1) there is more than one interest rate to the operation of the economy, (2) money and goods are substitutes and treat expected inflation rates as an opportunity cost of holding money instead of goods, and (3) permanent income is the primary determinant of money demand as it is not very sensitive to the changes in differentials of expected rates of alternative assets and money (Ho, 2003). According to Eatwel et al. (1987), monetarists were early critics of the influential Keynesian theory's highly elastic demand for money with respect to short-run changes in the interest rate (on liquid short-term assets) which, in extreme form, becomes a liquidity trap. Baumol (1952) found that interest on savings deposits and on short-term securities has elasticities that are smaller than -0.5. To show the elasticity, the variables $M 2, Y$ and $R$ were transformed into natural logarithms; i.e., $M 2_{\mathrm{i}}=\operatorname{In} M 2_{\mathrm{i}}-\ln P, i=1,2,3$ and $Y=\operatorname{In} Y-\ln P$; nominal interest rates are used unchanged as percentage figures. The variables used in this study are in logarithmic form, as is the case for most economic studies of this nature done in South Africa on real money demand (Todani, 2007).

\section{DATA}

The paper employs monthly South African data for the period January 1971 through December 2010 (i.e., 40 observations). $M 2$ is used as the measure of money stock. The principal sources for the data on monetary aggregates are the South African Reserve Bank (SARB) and Statistics South Africa. The study investigates the longrun relationship between real money demand $(M 2)$, real income $(Y)$ and interest rates $(R)$ in South Africa, with the latter two variables being the explanatory variables. The monthly interest rate data obtained for this study were annualised (aggregated per annum). The resultant time series data were then subjected to different types of preliminary and co-integration tests implemented in the subsequent section. 
A time series is a sequence of observations taken of some process that varies over time (Hawkins \& Weber, 1980). This type of data poses many challenges to researchers, especially econometricians, particularly relating to differing properties of stationary and non-stationary data (Johansen, 1991). Most empirical studies based on time series data assume that the underlying time series data is stationary, such that the mean and variance do not vary systematically over time (Fathi \& Naifar, 2006). In reality, it is, however, known that many macroeconomic time series data are not stationary (Hill, Griffiths \& Judge, 2001). Economic time series are generally integrated in the $1^{\text {st }}$ order so that it becomes stationary only after taking their first differences. The problem is that when a non-stationary time series is applied in a regression model, the results may spuriously indicate a significant relationship where there is none (Hill et al., 2001).

\section{Model Specification}

Data availability considerations have previously led to relatively simple specifications of money demand (Browne, Fagan \& Henry, 1997). Following this tradition, the current study focuses on a model in which real money balances are related to real income and prime interest rates, whereby the short and long-term interest rates are the opportunity costs of the narrow and broad aggregates, respectively. In this context, it is useful to start the analyses of the long-run properties of the data within the multivariate framework put forward by Johansen (1991). This makes it possible to consider a variety of approaches, other than the single-equation approach according to which money would be a function of exogenous variables. This approach has been used in many studies (see Monticell \& StraussKahn (1992); Wesche (1997); Ziramba (2007); and Obi et al. (2010). In order to investigate the relationship between real money demand, on the one hand, and a pair of money market components on the other, we specify the following multivariate model using annualised monthly data following Johansen (1991):

$$
M 2_{t}=\beta_{1}+\beta_{2}\left(Y_{t}\right)+\beta_{3}\left(R_{t}\right)+\mu_{t}
$$

where:

$M 2=$ real money demand (data from SARB)

$\beta_{1}=$ is the intercept

$\beta_{2}=$ represents coefficients of the explanatory variable $Y$ (real income)

$\beta_{3}=$ represents coefficients of the explanatory variable $R$ (prime interest rates)

$\mu=$ is the error term

The regression coefficient on income, as influenced by economic activity, is expected to be positive while the coefficient of the prime interest rate is expected to be negative (Obi et al., 2012). In other words, as economic activities grow, demand for money increases. Therefore, real income $\left(\beta_{2}\right)$ is expected to be positive and the prime interest rate $\left(\beta_{3}\right)$ is expected to be negative; the demand for money (M2) weakens as savings increase (due to an increase in the prime interest rate).

\section{Preliminary Examination of the Data}

As the first step, it is always advisable to examine the data under study before pursuing formal tests to check variables of stationarity. Preliminary indications of the time series properties of the three variables are illustrated in Figures 1(A), 1(B) and 1(C) in the Appendix. These diagrams provide the (natural logarithms) trends plots of $M 2, Y$ and $R$. This gives an initial idea about the likely nature of the time series (Gujarati, 2003). The natural logarithm plots of real money $(M 2)$ and real income $(Y)$ against time period (39 years) are done to show the elasticities of these variables.

As illustrated, both real money demand (M2) and real income $(Y)$ in Figures 2(A) and 2(B) are trending upward, suggesting that their means are changing over time. Seasonal variations are apparent in $M 2$ and $Y$, but less so in $R$. This may show that real money and real income time series are not stationary. On the other hand, Figure 1(C) (prime interest rate plot) shows some stationarity. Gujarati (2003) states that the above realisations are the starting point of any analysis. Seasonal variations can be better examined through the autocorrelation function of the 
first differences (Gujarati, 2003). The formal tests of stationarity, which are sample correlogram and Augmented Dickey Fuller (ADF) under unit root test and their co-integration tests and Error Correction Model (ECM), are then applied.

For each aggregate, vector autoregression (VAR) models are estimated and the Johansen technique is applied to test for the number of cointegration vectors and, when cointegration is present, the parameters of these long-run relations are to be estimated. In order to assess the robustness of the results to the list of variables considered, different systems were estimated. First, a bivariate system involving real money and real income - in logarithmic scale - and then increasing the number of variables by including long and short-term interest rates. In all cases, the deterministic component is an unrestricted constant, corresponding to a model with drift, therefore without any trend component in the long-run system. Theoretically, the number of long-run relations found may be an increasing function of the number of variables.

\section{Testing for Randomness (Autocorrelation)}

Autocorrelation refers to the correlation of a time series with its own past and future values (Ziramba, 2007). It is sometimes called lagged correlation or serial correlation, which refers to the correlation between members of a series of numbers arranged in time (Engle \& Granger, 1987). According to Chatfield (2004), the firstorder autocorrelation co-efficient is the simple correlation coefficient of the first $N-1$ observations, $x_{t}, t=1,2, \ldots, N$ -1 and the next $N-1$ observations, $x_{t}, t=2,3, \ldots, N$. The quantity $r_{k}$ is called the autocorrelation coefficient at lag $k$. The plot of the autocorrelation function, as a function of lag, is also called the correlogram, denoted by $\rho k$ and defined as covariance at lag $k$ over variance. The generalised equation for the autocorrelation function is of the following order, in line with Chatfield (2004).

$$
r_{k}=\frac{\sum_{i=1}^{N-k}\left(x_{i}-\bar{x}\right)\left(x_{i+k}-\bar{x}\right)}{\sum_{i=1}^{N}\left(x_{i}-\bar{x}\right)^{2}}
$$

where the quantity $r$ is called the autocorrelation coefficient at lag $k, N$ is the number of observations, and $t$ is the period in years. For a random series, lagged values of the series are uncorrelated. The plot is illustrated in Figures 2(A), 2(B) and 2(C). The graphs show the distribution of the random error terms around the mean. Therefore, if a time series is stationary, the autocorrelation coefficient at various lags remain around zero and decline quickly; but with a non-stationary time series, the autocorrelation coefficient starts at a high value and declines slowly toward zero as the lag lengthens (Falkena et al., 1991). The correlogram illustrated in Figures 2(A) and 2(B) depicts that both real money $(M 2)$ and real income $(Y)$ are non-stationary while the prime interest rate $(R)$ in Figure 2(C) shows the probability that this data series is stationary. Various researchers, such as Engle and Granger (1987), Kennedy (1998), Gujarati (2003), and Ziramba (2007), show that macroeconomic data are non-stationary because they are characterised by a random walk, even after a deterministic trend is removed. This means that the current period's value equals the last period's value plus a random error.

Because the data followed a specific trend, the unit root test is applied to determine whether the series is consistent with a stochastic trend (an I(1) process) or if it is consistent with stationary (an I(0) process) deterministic trend (Knight, 1966). This test suggests that the tau-statistic $(\tau)$ must take larger negative values than usual in order for the null hypothesis ( $\delta=0$, a unit root non-stationary process) to be rejected in favour of the alternative hypothesis $(\delta<0$, a stationary process). In order to control for the possibility of the error term in one of the equations under the ADF test, additional terms are included. These additional terms are the sum of lagged values of dependent variables added to the explanatory variables to make an autocorrelation (Hill et al., 2001:344). Thus, in adapting Gujarati (2003), the ADF equation is as follows:

$$
\Delta Y_{t}=\beta_{1}+\beta_{2} t+\delta Y_{t-1}+\sum_{k=1}^{m} \alpha_{k} \Delta Y_{t-1}+u
$$


where $\mu_{\mathrm{t}}$ is a white noise error term and $m$ is the number of lags for $\Delta \mathrm{Y}_{t-1}$. In this study, the $m$ (upper limit) is equal to five and the results are as follow:

Table 1: Autocorrelation Test Statistics

\begin{tabular}{|l|c|c|c|c|c|c|c|}
\hline Variables & Coefficient $(\boldsymbol{\delta})$ & ADF test $(\boldsymbol{\tau})$ & $\Delta$ Variables & ADF test $(\boldsymbol{\tau})$ & $\mathbf{R}^{\mathbf{2}}$ & Adj. $^{\mathbf{2}}$ & DW \\
\hline$M 2$ & 0.494 & 2.557 & $\Delta \mathrm{M}_{t}$ & -1.951 & 0.450 & 0.389 & 1.880 \\
\hline$Y$ & 0.435 & 2.092 & $\Delta \mathrm{Y}_{t}$ & -2.395 & 0.342 & 0.269 & 1.848 \\
\hline$R$ & 0.76 & 0.373 & $\Delta \mathrm{R}_{t}$ & -2.111 & -2.395 & 0.181 & 1.665 \\
\hline
\end{tabular}

The results in Table 1 show that the estimated values of $\delta$ (the coefficient of $M 2=0494, Y=0.435$ and $R=0.76)$ are positive, as are the associated tau-statistic values $(\tau)(2.557,2.092$ and 0.373 , respectively). This indicates that the time series for those three variables would be non-stationary (Gujarati, 2003). Therefore, the null hypothesis is not rejected. Thus, money demand $(M 2)$, real income $(Y)$, and the prime interest rate $(R)$ are not stationary.

\section{Estimation and Testing for Co-Integration}

A number of estimation procedures for co-integrated processes have been discussed and used in other empirical studies (Engle \& Granger, 1987). This study employs a testing and estimation approach developed by Johansen (1991) which has several advantages vis-à-vis the widely used Engle and Granger two-step-procedure. It is well-known that many economic time series are non-stationary in their levels but stationary in first differences (Falkena, 1991). Such variables are said to be integrated in the first order, denoted by I(1). A simplifying assumption is thus made that nominal money and prices share the same $\mathrm{I}(2)$ trend and that they are homogeneous of degree one, such that $m_{t}-p_{t}$ is I(1). This transformation enables the money demand model to be formulated in real rather than nominal terms, thus allowing a potentially complicated I(2) model to be set up in I(1) space in which analysis can proceed using conventional co-integration techniques (Todani, 2007).

Non-stationary time series variables should not, as a rule, be used in regression models in order to avoid the problem of a spurious regression (Hill et al., 2001). Preliminary data analysis of this study found that the individual time series in the direction of unit root were all I (1) or non-stationary. The real income and prime interest rate variables were co-integrated when they were $\mathrm{I}(1)$ before and after some linear combination of them becomes $\mathrm{I}(0)$. Therefore, their entry into the estimating equation will not create spurious results (Kennedy, 1998). From the cointegration model, the residuals are estimated and we use a unit root test to find out whether our variables cointegrate and determine whether there is a long-run relationship between them. The results showed that $t=-8.174$, 28.374, $-0,815 ; \mathrm{R}^{2}=0.960 ; \mathrm{Adj} \cdot \mathrm{R}^{2}=0.957 ; \mathrm{F}=403.569$ and $\mathrm{DW}=0.775$. The results also showed that the F-test is very high $(\mathrm{F}=10.256)$, meaning that the model, as a whole, is statistically significant. The computed $t$-statistic of $Y$ is statistically significant, but the $t$-statistic of $\mathrm{R}$ is statistically not significant. The $\mathrm{R}$-square is high $(0.227)$, but the Durbin Watson (DW) value is very low (1.665), indicating that the model has an autocorrelation problem. This might be the result of the time series being non-stationary. However, if the R-square is greater than DW result, it shows that the estimated regression might be spurious. To check this, co-integration tests were done and Table 2 presents the results:

Table 2: The Johansen Co-Integration Tests

\begin{tabular}{|c|c|c|c|c|}
\hline \multicolumn{5}{|c|}{ Maximun Eigenvalue Test } \\
\hline \multirow[t]{2}{*}{ Null Hypothesis } & \multirow{2}{*}{ Alternative Hypothesis } & \multicolumn{2}{|c|}{ Test Statistic } & \multirow[t]{2}{*}{ 95\% Critical Value } \\
\hline & & 1970-1995 & 1996-2008 & \\
\hline $\mathrm{r}=0$ & $\mathrm{r}=1$ & 29.91 & 30.27 & 21.07 \\
\hline $\mathrm{r} \leq 1$ & $\mathrm{r}=2$ & 5.16 & 21.90 & 14.90 \\
\hline $\mathrm{r} \leq 2$ & $\mathrm{r}=3$ & 1.4 & 0.01 & 8.18 \\
\hline \multicolumn{5}{|c|}{ Trace Test } \\
\hline \multirow[t]{2}{*}{ Null Hypothesis } & Alternative Hypothesis & \multicolumn{2}{|c|}{ Test Statistic } & 95\% Critical Value \\
\hline & & $1970-1995$ & 1996-2008 & \\
\hline $\mathrm{r}=0$ & $r \geq 1$ & 36.21 & 52.19 & 31.53 \\
\hline $\mathrm{r} \leq 1$ & $\mathrm{r} \geq 2$ & 6.31 & 21.92 & 17.95 \\
\hline $\mathrm{r} \leq 2$ & $\mathrm{r}=3$ & 1.14 & 0.01 & 8.18 \\
\hline
\end{tabular}

Note: $r$ denotes the number of co-integration vectors. $\ln M 2, \ln Y$ and $\ln R$ are used for co-integration tests. Maximum lag in VAR $=2$ 
Since the computed maximum eigenvalue and trace test statistics for the two periods are significantly greater than the critical values in all three forms of unit root and in absolute value, as shown in Table 2, the null hypothesis $(\delta=0)$ is rejected and therefore a unit root is present. Thus, the residuals from our regression are $\mathrm{I}(0)$ or stationary. This leads us to conclude that $M 2, Y$, and $R$ are co-integrated and our econometric model represents the long-run money demand in South Africa. Table 3 reports the co-integration vectors for economic variables found to be co-integrated as shown by the tabulated findings.

Table 3: The Co-Integration Vectors

\begin{tabular}{|c|c|c|c|c|}
\hline Sample & Vector & $\operatorname{lnM2}$ & $\ln$ & $\ln \mathbf{R}$ \\
\hline $1970-2008$ & 1 & 1.59 & -1.86 & -0.28 \\
\hline $1996-2008$ & 1 & 1.30 & 1.81 & - \\
\hline $1998-2008$ & 1 & -2.54 & 2.74 & -0.13 \\
\hline $2004-2008$ & 2 & 2.84 & -2.16 & 2.07 \\
\hline
\end{tabular}

Note ' $r$ ' denotes the number of co-integration vectors. $\operatorname{lnM} 2, \ln \mathrm{Y}$ and $\ln \mathrm{R}$ used for co-integration tests. Maximum lag in VAR $=2$

A co-integration regression is also run by estimating the augmented-DF regression; but in this case, summation of change of error terms is used in the form of in-line with Obi et al., (2012):

$$
\Delta U_{t}=\beta_{1}+\beta_{2} t+\delta U_{t-1}+\alpha \sum_{k=1}^{m} \Delta U_{t-1}
$$

Co-integration tests are also performed on the differenced series since at their levels, the variables are nonstationary. The unit root test results indicate that all variables are I(1). Both the maximum eigenvalue and trace tests reject the null hypothesis of no co-integration at the 5\% level of significance. Establishing that the variables are cointegrated means that the short-run dynamics of their relationships may be specified as a vector error-correction (VEC) model (Ziramba, 2007).

\section{Error Correction Mechanism (ECM)}

Naturally, if the series are co-integrated, an error-correction model becomes necessary to investigate the short-run dynamics of the co-integrated series (Batini \& Nelson, 2000). Instead, we consider the variance decompositions of the series as a way to examine the short-run effects. A co-integration between variables does not necessarily provide a full warrant that equilibrium exists in the model (Peters \& Beintum, 2009). Therefore, to correct this disequilibrium issue, an error correction mechanism is used to estimate the push back to the model toward the long-run equilibrium whenever it moves away (Engle \& Granger, 1987). The vector error correction (VEC) model following Todani (2007) is of the form:

$\Delta \mathrm{M} 2_{t}=\alpha_{1}+\alpha_{2} \delta \mathrm{Y}_{t}-\alpha_{3} \delta \mathrm{R}_{t}-\alpha_{4} \mathrm{U}_{t-1}+\varepsilon_{t}$

where

$\mathrm{M} 2_{t}=$ Real money demand

$\mathrm{Y}_{t}=$ Real income

$\mathrm{R}_{t}=$ Rrime interest rate

$\alpha_{1}=$ is the intercept

$\alpha_{2}=$ represents coefficients of the explanatory variable $Y$ (real income)

$\alpha_{3}=$ represents coefficients of the explanatory variable $R$ (prime interest rates)

$\mu=$ is the error term

The ' $\alpha$ ' is expected to be negative, precisely to impact real money demand negatively in order to restore the equilibrium (Gujarati, 2003). The value of $\alpha_{2}$ shows that there is an anticipation of taking actions related to monetary policy change in South Africa because these decisions taken by Monetary Policy Committee (MPC) are made every quarter of the year $(0.25)$. Therefore, the equilibrium error is corrected by using error terms to tie the 
short-run behaviour of real money demand to its long-run values. With the data used in this paper, the results from the above equation are:

$$
\Delta M 2_{t}=6832.405+0.480 \Delta Y_{t}+785.260 \Delta R_{t}-0.227 U_{t-1}
$$

By having a negative coefficient (-0.227) of $U_{\mathrm{t}-1}$ shows that when $M 2$ is above its equilibrium, it will start declining in the next period to correct equilibrium error (Cuthbertson, 1996).

\section{CONCLUDING REMARKS}

Although we believe that the results expressed in this paper have general applicability to all research on long-run economic relationships using the Johansen's approach, this particular use of the South African money demand in this study is motivated by the fact that a stable money demand function is a prerequisite for the use of monetary aggregates in the conduct of monetary policy. Based on the preliminary data analysis, the test shows that the money demand relations were unstable, for the most part, of the sample period until around the year 1999 when the relationship showed some stability tendencies. The monetarist model of inflation, which assumes long-run neutrality, concludes that if the money supply rises by more than demand, then expenditure will rise with a consequent rise in output and prices. If output is at maximum - or close to maximum capacity - the 'direct relationship' between money and prices becomes apparent.

The Johansen method to co-integration and preliminary data tests adopted in this study enabled a variety of theory-consistent identification schemes to be explored in identifying the demand for money function for the aggregate $M 2$ in South Africa. The paper found that a stable long-run, co-integrated money demand relation is still identifiable, notwithstanding all economic developments that have taken place in South Africa, including financial liberalisation, integration into the world economy, opening up of the economy, and so forth. This is consistent with Todani's (2007) findings. The results of the study confirm the presence of a long-run relationship between real money demand, real income and interest rates in South Africa. These results are consistent with the real money demand indicators confirmed in other countries by different researchers (Batini \& Nelson, 2000). The results confirm the expectation of a positive relationship between real money demand and real income as well as a negative relationship between real money demand and interest rate.

This study discloses that people make adjustment decisions about their demand for money a few days before Monetary Policy Committee meets. This is explained by the negative result (-0.227) obtained from the error correction testing as it measures the short term changes. The policy implication of this finding arises from the proposition that the effectiveness of monetary policy, as a stabilisation anti-inflationary tool, depends on the existence of a stable and well-understood link between money and prices. Notwithstanding the effect of nonmonetary factors (at least as initiating shocks), this model seems to work well for South Africa and, hence, the monetarist anti-inflationary prescription is bound to be useful. This conclusion is due to inflation being affected by exogenous shocks and responding to monetary policy. In fact, Joshi and Little (1994) attribute the low inflationary environments to the quick reaction by the authorities to changes in response to financial determinants such as price changes; this could also be said about South Africa.

\section{ACKNOWLEDGEMENTS}

The researchers would like to acknowledge Professor P. Obi and the anonymous referees for some highly useful comments during this research study and in the revisions of this paper. We are also grateful to Vaal University of Technology for providing funding for this study.

\section{AUTHOR INFORMATION}

Ferdinand Niyimbanira is currently a Lecturer in Economics in the Faculty of Management Sciences at Vaal University of Technology (VUT), South Africa. He is a PhD Candidate at North-West University (NWU), South Africa. He has published many papers in national and international journals. His current research interests are macroeconomics and financial Economics. E-mail: ferdinandn@vut.ac.za 
Job Dubihlela is currently a Senior Lecturer in the Faculty of Management Sciences at Vaal University of Technology (VUT), South Africa. He is a seasoned banker turned academic. He completed a PhD at North-West University (NWU), South Africa. He has published various papers in peer-reviewed international and national journals. His current research interests are financial economics and development economics. E-mail: job@vut.ac.za (Corresponding author)

\section{REFERENCES}

1. Anderson, R.C. Mansi S.A., \& Reeb D.M. (2003). Founding Family Ownership and the Agency Cost of Debt. Journal of Financial Economics, 68(2):263-285.

2. Batini, N. \& Nelson, E. (2000). Optimization Horizons for Inflation Targeting. Working Paper, No.119, London: The Bank of England, Economic Research Department.

3. Baumol, W. (1952). The Transactions Demand for Cash: An Inventory Theoretical Approach. Quarterly Journal of Economics. 66(1):545-556.

4. Bernanke, B. S. (2006). Monetary Aggregates and Monetary Policy at the Federal Reserve: A Historical Perspective. Fourth ECB Central Banking Conference, Frankfurt, Germany. Available:

http://www.federalreserve.gov/newsevents/speech/bernanke20061110a.htm (Accessed: 10 Febrauary 2012).

5. Bernanke, B. S. \& Gertler, M. (1999). Monetary Policy and Asset Price Volatility. Federal Reserve Bank of Kansas City. Economic Review (Fourth Quarter):17-51.

6. Chatfield, C. (2004). The analysis of time series: An introduction $\left(6^{\text {th }}\right.$ edition). NY: Chapman \& Hall/CRC.

7. Cecchetti, S. G.; Genberg, H.; Lipsky, J. \& Wadhwani, S. (2000). Asset Prices and Central Bank Policy, Geneva Reports on the World Economy, CEPR. International Center for Monetary and Banking Studies, 2(5):64-75.

8. Courakis, A.S. (1984). Constraints on bank choices and financial repression in less developed countries. Oxford Bulletin of Economics and Statistics, 46(4):341-370.

9. Cuthbertson, K. (1996). The expectations hypothesis of the term structure: The UK interbank market. Economic Journal, 106(1):578-592.

10. Eatwell, J. Milgate, M \& Newman, P. (1987). The New Palgrave: A Dictionary of Economics. Vol.3. New York, The Stockton Press.

11. Engle, R. \& Granger, W. (1987). Co-integration and Error corrections: Representation, Estimation and testing. Econometrica, 55(2):251-276.

12. Falkena, H.B. Meijer, J. H. \& Van der Merwe, E. J. (1991). Financial Policy in South Africa. Cape Town, Southern Book Publishers.

13. Fathi, A. \& Naifar, N. (2006). Credit Default Swap Rates and Equity Volatility: A Nonlinear Relationship. The Journal of Risk Finance, 7(4):348-371.

14. Fisher, I. (1911). The Purchasing Power of Money. NY: MacMillan Publishers.

15. Fischer, S. \& Merton, R. C. (1984). Macroeconomics and Finance: The Role of the Stock Market. Carnegie-Rochester Conference Series on Public Policy, 21(1):57-108.

16. Friedman, M. (1988). Money and the Stock Market. Journal of Political Economy 96 (2):221-45.

17. Gibson, W. E. (1976). Demand and Supply Functions for Money: A Comment. Econometrica, 44(2):387389.

18. Gujarati, D. (2003). Basic Econometrics. $4^{\text {th }}$ Edition. New York, McGraw Hill.

19. Haug, A. \& Lucas, R. (1996). Long-run money demand in Canada: In search of Stability. The Review of Economics and Statistics, 78(2):345-348.

20. Harb, N. (2003). Money Demand Function: Heterogeneous Panel Application. http://faculty.uaeu.ac.ae/nasri.harb/research/Money Demand Function_all.pdf. Accessed: 11 March 2012).

21. Havrilesky, T.M. (1995). The Pressures on American Monetary Policy. Second edition. Boston, Kluwer Academic Publishers.

22. Hawkins, C. \& Weber, J. (1980). Statistical Analysis: Application to Business and Economics. London, Harper \& Row Publishers.

23. Henderson, J.V. \& Poole, W. (1991). Principles of Macro-economics. Toronto. D.C. Heath and Company.

24. Hill, R.C. Griffiths, W.E. \& Judge, G. G. (2001). Undergraduate Econometrics. Second Edition. USA, Wiley. 
25. Ho, W. S. (2003). Money Demand in Macau and its Estimation. Macau, Monetary Authority of Macau. http://www.amcm.gov.mo/publication/quarterly/July2003/Md_en.pdf (Accessed: 12 November 2011).

26. Hurn, A.S. \& Muscatelli, V.A. (1992). The long-run properties of the demand for M3 in South Africa. South African Journal Of Economics, 60(2):93-101.

27. Hussien, A. A.; Ahmed, S. \& Yousaf, M. (2012). Long run money demand in South Africa: A cointegrated var approach. International Journal of Economics Research, 3(4):97-120.

28. Johansen, S. (1991). Estimation and Hypothesis Testing of Cointegration Vectors in Gaussian Vector Autoregressive Models. Econometrica, 59(1):1551-1580.

29. Jones, C.M. Lamont, R. \& Lumsdaine, R. L. (1998). Macroeconomic News and Bond Market Volatility. Journal of Financial Economics, 47(1):315-337.

30. Kennedy, P. (1998). A Guide to Econometrics. $4^{\text {th }}$ edition. UK:Cambridge: MIT Press.

31. Kent, C. \& Lowe, P. (1997). Asset-Price Bubbles and Monetary Policy, Research Discussion Paper, No.9709. Economic Research Department, Reserve Bank of Australia.

32. Knight, W. (1966). A Computer Method for Calculating Kendall's Tau with Ungrouped Data. Journal of the American Statistical Association, 61(314):436-439.

33. Muscatelli, V.A. \& Spinelli, F. (2000). The long-run stability of the demand for money: Italy $1861-1996$. Journal of Monetary Economics, 45(3):717-739.

34. Meltzer, A. H. (1963). The Demand for Money: The Evidence from the Time Series. Journal of Political Economy, 71 (3):223-34.

35. Moll, P.G. (2000). the demand for money in south africa: parameter stability and predictive capacity. South African Journal of Economics, 68(2):80-89.

36. Nell, K.S. (2003). The stability of m3 money demand and monetary growth targets: The case of South Africa. Journal of Development Studies, 39:155-180.

37. Nell, K.S. (2004). The structuralist theory of imported inflation: an application to South Africa. Applied Economics, 36(13):1431-1444.

38. Obi, P. Dubihlela, J. \& Choi, J.G. (2012). Equity Market Valuation, Systematic Risk, and Monetary Policy. Journal of Applied Economics, 44 (27):3605-3613.

39. Perlman, M. (1981). Macroeconomics. Second edition. London, George Weindenfeld and Nicolson Ltd.

40. Peters, R. S. \& Beintum, M. J. (2009). Going fishing: State budget deficits drive an expanding net of unclaimed property collections. Journal of Multistate Taxation and Incentives, (July), 19(4):1-10.

41. Ramanathan, R. (1989). Introductory Econometrics: With applications. Third edition. NY: The Dryden Press.

42. Shapiro, E. (1974). Macroeconomics Analysis. $3^{\text {rd }}$ edition. NY: Harcourt, Brace Jovanovich, Inc.

43. Shapiro, E. (1966). Macroeconomics Analysis. NY: Harcourt, Brace and World, Inc.

44. Spencer, P. (1997). Monetary integration and currency substitution in the EMS: The case for a European Monetary Aggregate. European Economic Review, 41(1):1403-1419.

45. Talvas, G.S. (1989). Demand for money in South Africa: A test of the Buffer Stock Model. South African Journal of Economics, 57(1):1-13.

46. Tlelima, T. \& Turner, P. (2004). The demand for money in South Africa specification and tests for instability. South African Journal of Economics, 72(1):25-36.

47. Todani, K.R. (2007). Long-run M3 demand in South Africa: A cointegrated VAL model. South African Journal of Economics, 75(4):681-692.

48. Wesso, G.R. (2002). Broad money demand and financial liberalisation in South Africa. South African Reserve Bank, Occasional Paper No.18, November.

49. Wesche, K. (1997). The stability of European money demand: An investigation of M3H. Open Economies Review, 8(1):371-392.

50. Whittaker, J. (1985). The demand for money in South Africa: Towards a more accurate perspective. South African Journal of Economics, 53(2):184-196.

51. Yunez-Naude, A. (1992). El tratado de libre comercio y la agricultura mexicana; un enfoque de equilibrio general aplicado. Estudios económicos. El Colegio De México, México, 7:225-64.

52. Ziramba, E. (2007). Demand for money and expenditure components in South Africa: An assessment from unrestricted error-correction models. South African Journal of Economics, 75(3):412-424. 


\section{APPENDIX}

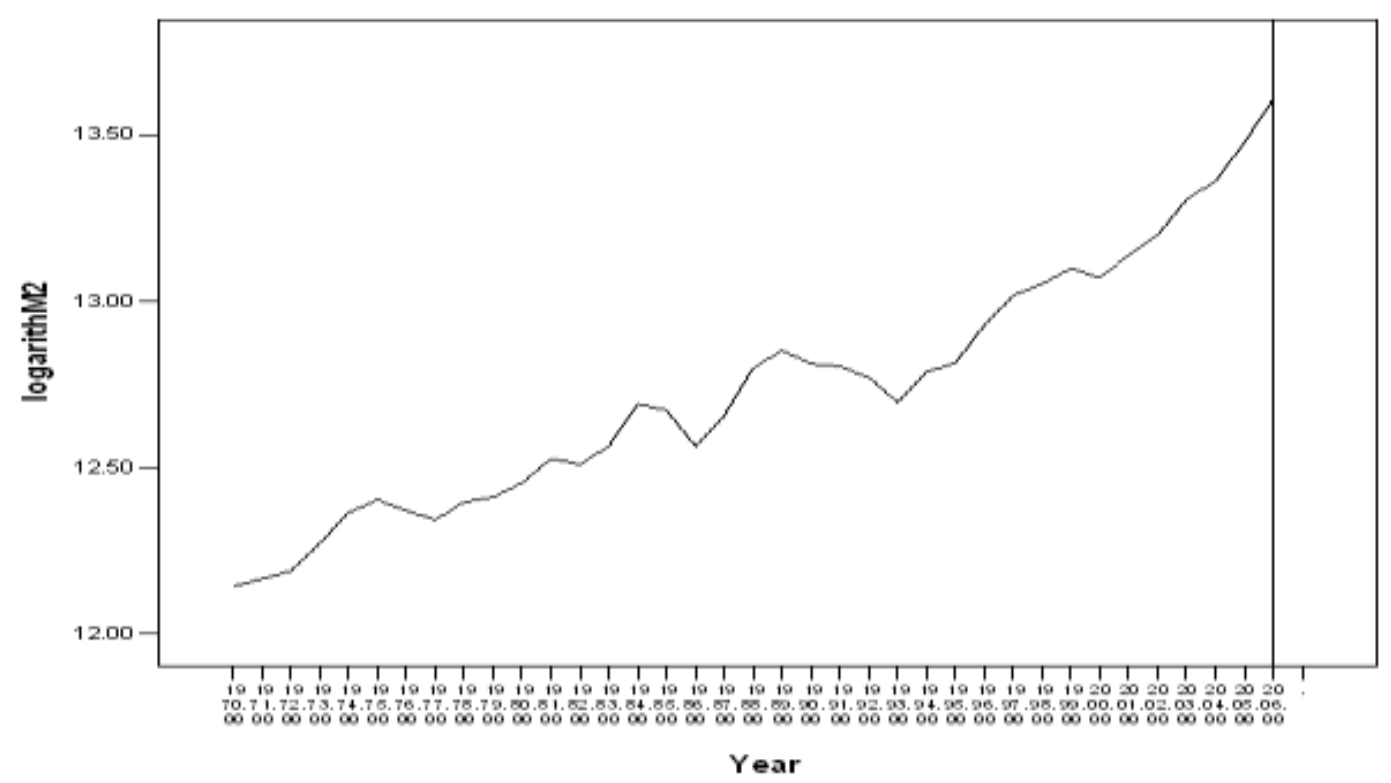

Figure 1(A): The Natural Logarithm of Real Money

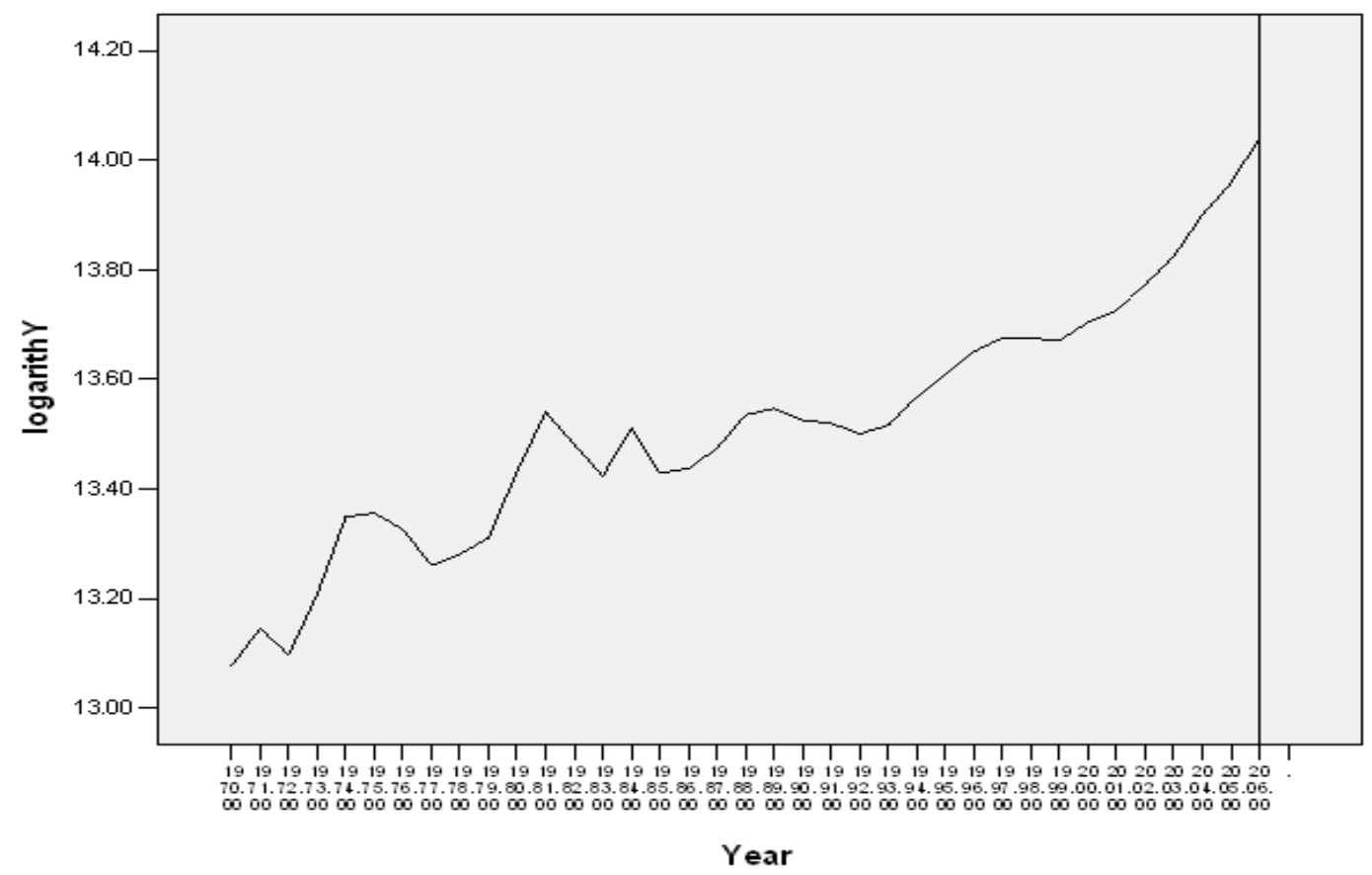

Figure 1(B): The Natural Logarithm of Real Income 


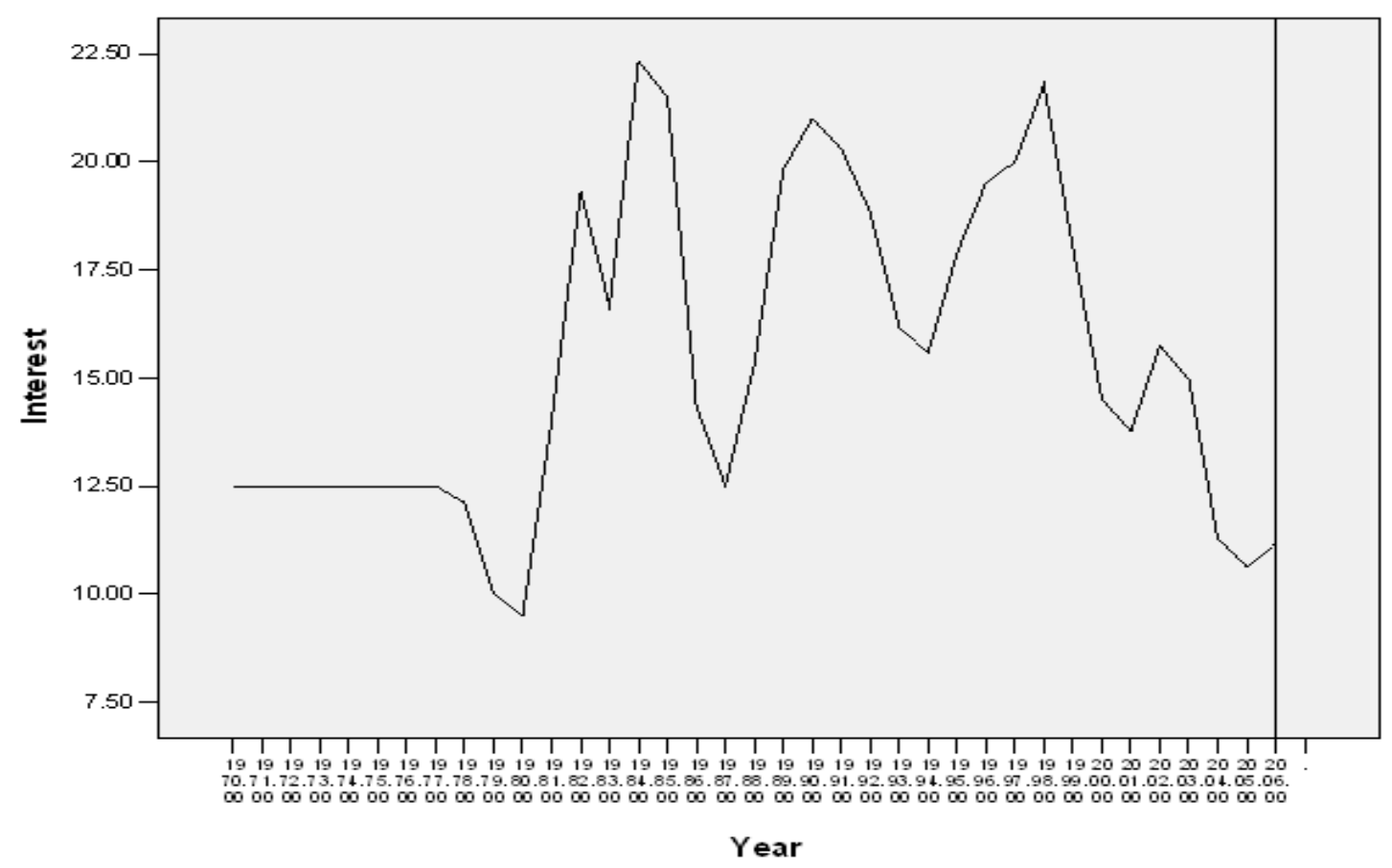

Figure 1(C): The Plot of Prime Interest Rate

\section{RealM2}

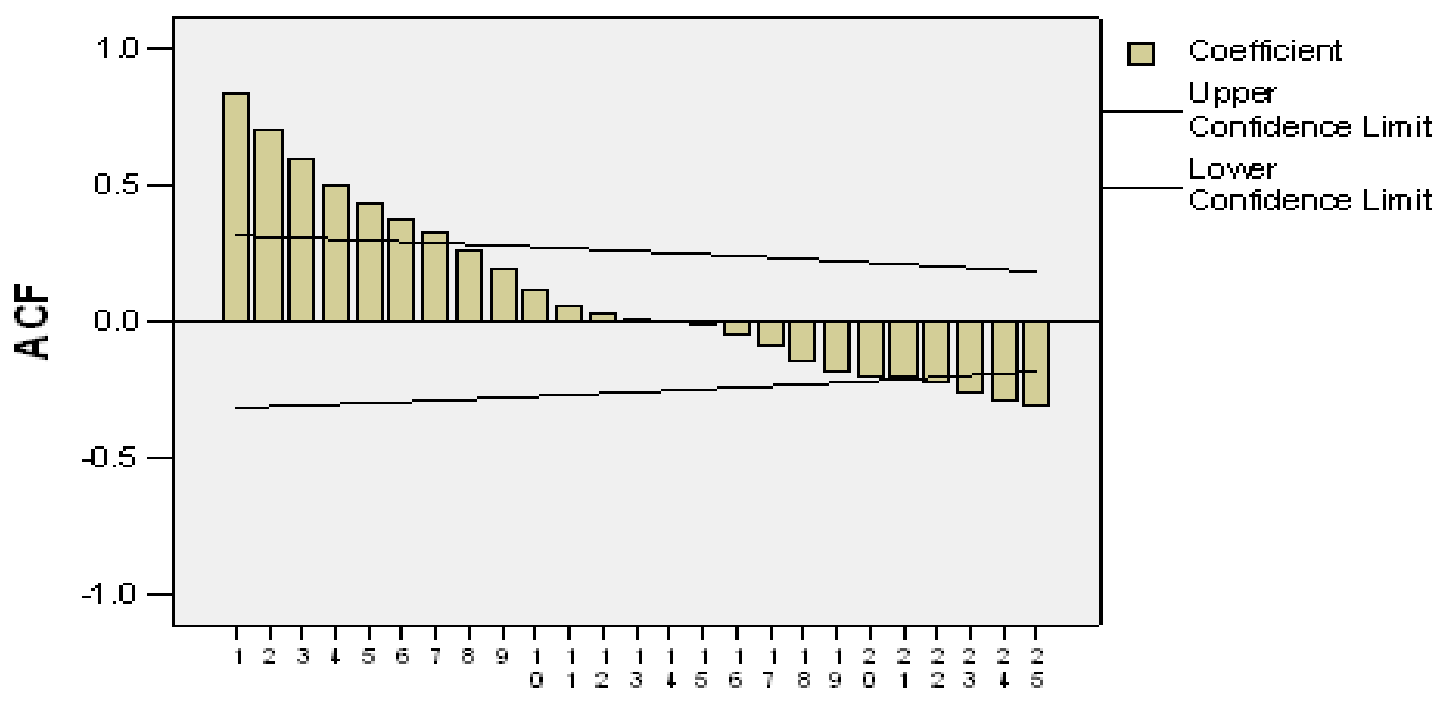

Lag Number

Figure 2(A): Sample Correlogram of Real Money (M2) 


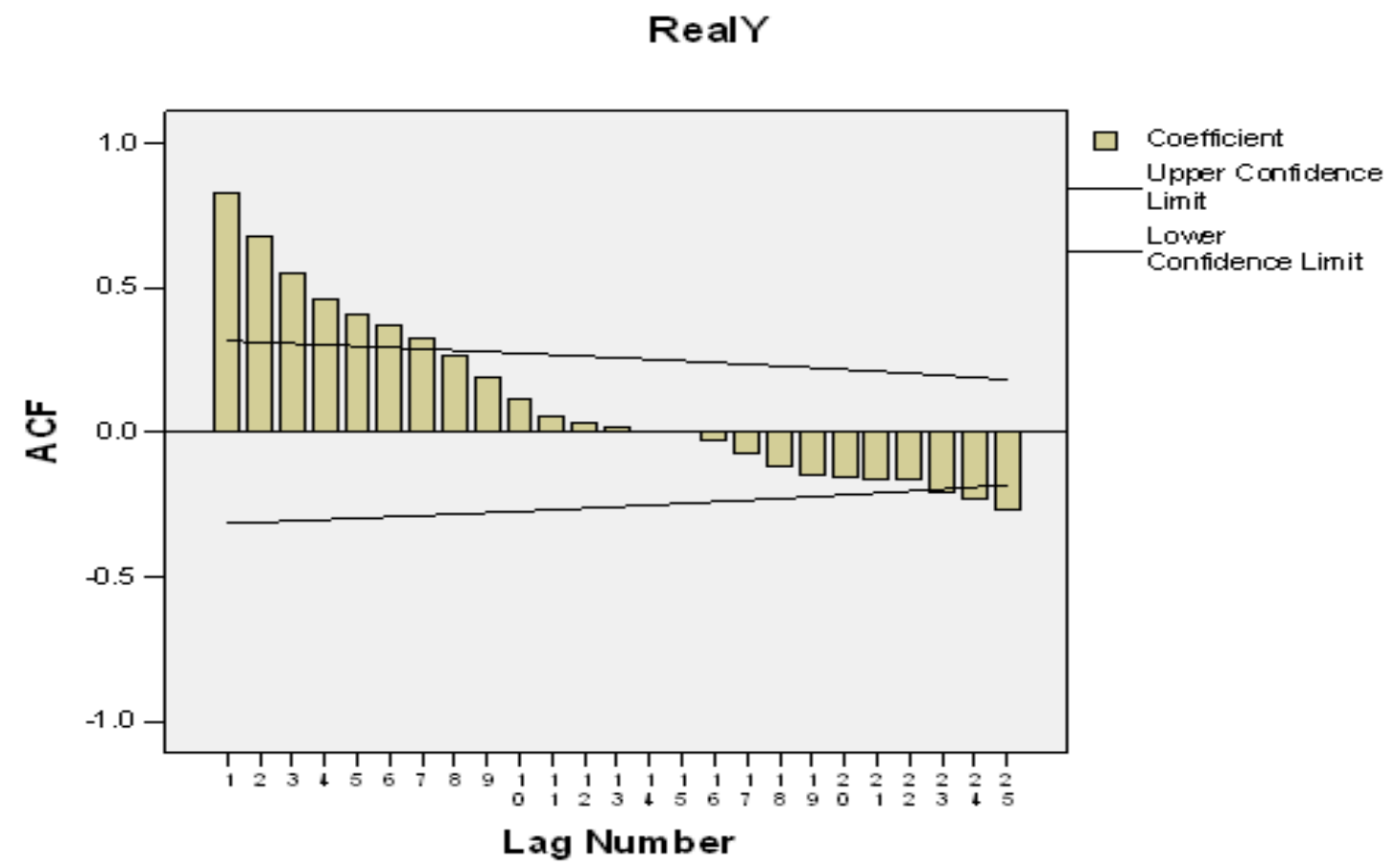

Figure 2(B): Sample Correlogram of Real Income (Y)

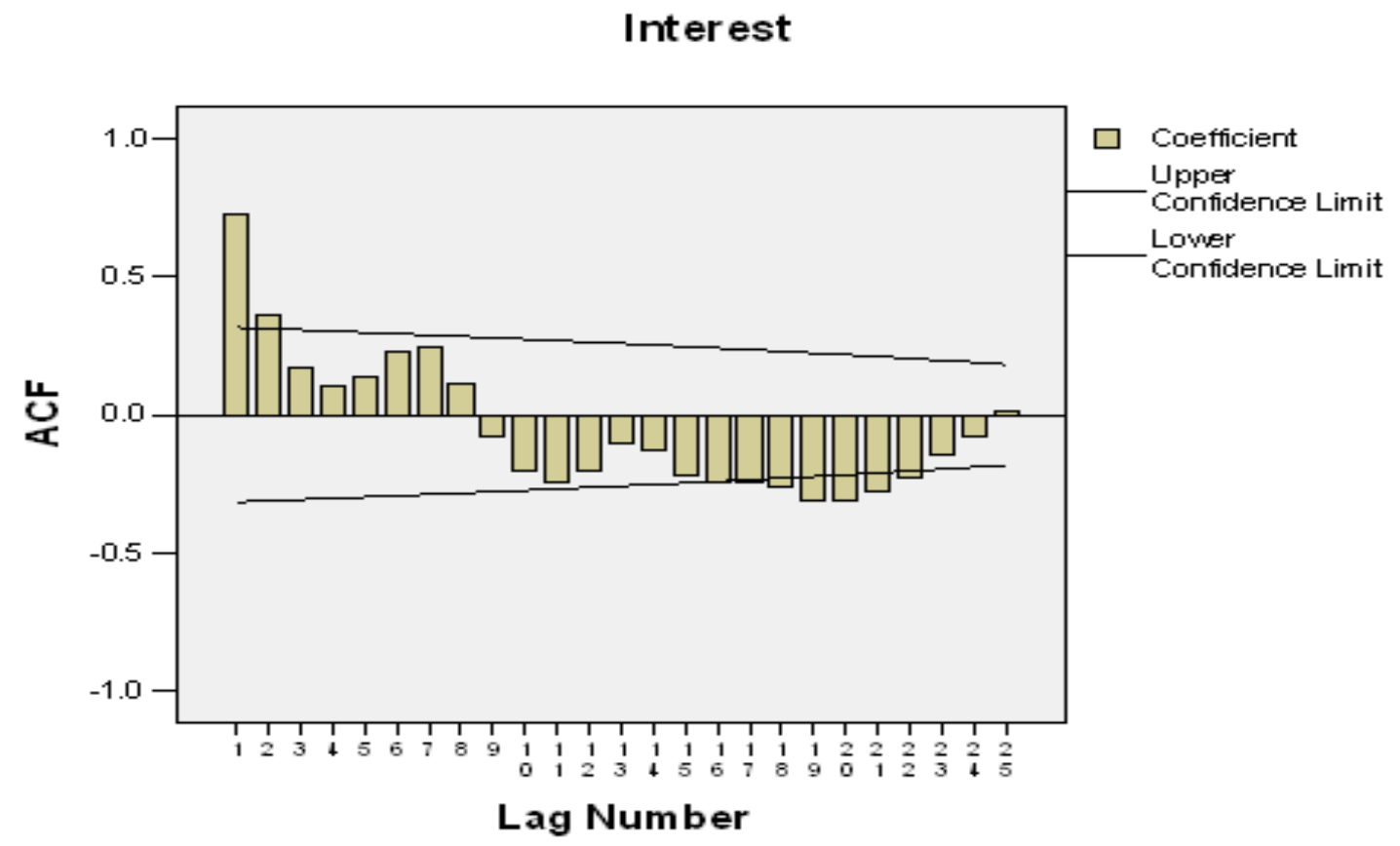

Figure 2(C): Sample Correlogram of Prime Interest Rate (R) 